\title{
Sedimentary and structural setting of the Aptian reservoir deposits in the Kasserine area, west-central Tunisia
}

\author{
Khaled Lazzez ${ }^{1}$, Marzouk Lazzez², Moez Ben Fadhel ${ }^{3}$, Ramla Ben Rabah² and Taher Zouaghi4,5 \\ 1 Université Tunis El Manar, Département de Géologie, Faculté des Sciences de Tunis, 2092 Tunis, Tunisia; (lazzezkhaled@yahoo.com) \\ ${ }^{2}$ Entreprise Tunisienne d'Activités Pétrolières (ETAP), 54 Avenue Mohamed V, 1002 Tunis, Tunisia; (marzouk.lazzez@etap.com.tn) \\ ${ }^{3}$ Institut Supérieur des Sciences et Technologies de l'Environnement, Département de Biotechnologie, Borj Cédria, Tunisia; (moez.benfadhel@yahoo.fr) \\ ${ }^{4}$ King Abdulaziz University, Faculty of Earth Sciences, Department of Geoexploration, 21589 Jeddah, Saudi Arabia; (taher.zouaghi2018@gmail.com; \\ tzouaghi@kau.edu.sa) \\ ${ }^{5}$ CERTE, Pôle Technologique de Borj Cédria, Laboratoire de Géoressources, 8020 Soliman, Tunisia
}

doi: $10.4154 / g c .2020 .06$

Article history:

Manuscript received May 13, 2019

Revised manuscript accepted February 18, 2020

Available online February 29, 2020

\begin{abstract}
The Aptian hydrocarbon-producing reservoirs, in the onshore Semmama and Douleb oil fields of west-central Tunisia are characterized by a heterogeneous flow with continuous decline. Petroleum exploration in this area requires detailed knowledge of the structural development of the basin and its relationship to the reservoir sequence and the source rock distribution. The structural configuration of west-central Tunisia is characterized by NE-SW, NW-SE and N-S deepseated faults, which outline tectonic structures and it is influenced by Triassic salt intrusions. During the Aptian period, the basin was extensive and shallow at the center, though moderately deep to the North. The northeast-southwest dominated synsedimentary extensional tectonics induced high and subsiding zones and thus controlled sedimentary deposition.

The Aptian reservoir is characterized by the lateral variation of sedimentary facies. The first zone, dominated by dolomitic lithofacies has been proven as a petroleum reservoir. The second zone corresponds to carbonate reef and para-reef facies. The third zone, trending north-south is characterized by shallow marine sedimentation, punctuated by episodes of detrital influx. The early Aptian is outlined by the emergence of Kairouan Island that took place in central Tunisia. This study facilitated mapping of the areas exhibiting hydrocarbon reservoir potential which resulted
\end{abstract}

Keywords: Aptian, West-central Tunisia, well and seismic data. A comparison with the surface data was conducted to better understand the dynamics of sedimentation within this region. Well log analysis of the Aptian layers was undertaken to verify the petrophysical characteristics of the reservoir. A geometric and structural model that shows the spatial distribution and evolution of the reservoir units, between the high platform and subsiding basin, is a potential exploration objective in west-central Tunisia.

\section{GEOLOGICAL SETTING}

The west-central Tunisia outcrops, belonging to the eastern Atlasic domain, are mainly composed of Mesozoic and Cenozoic layers deposited in several synclines, tilted blocks, and half graben basins (e.g. CHIHI \& BEN AYED, 1991; SAÏDI \& BELAYOUNI, 1994; CHIHI, 1995; ZOUAGHI et al., 2011, 2013). The structural framework (Fig. 1) is characterized by major NE-SW reverse faults, that outline major Atlasic folds, and by other regional NW-SE and E-W strike-slip faults that outline grabens and subsiding troughs. Other N-S transcurrent lineaments have dissected the pre-existing structures (e.g. MARTINEZ et al., 1990; CHIHI, 1995; ZOUAGHI et al., 2011, 2013).

Tectonic movements have controlled deformation within the Atlasic domain and, therefore, influenced sedimentary infilling and evolution of the basin and the platform structures (Figs. 2 and 3). Aptian structuring and sedimentary distribution seem to be generated by regional NNW-SSE Aptian extensional and/or transtensional tectonic deformation that changed to a NE-SW direction at the end of the Aptian (ZOUAGHI et al., 2011, 2013). based on the interpretation of the sedimentary succession from$$
\text { ZARTI, 2002; LAZZEZ et al., 2008; BEN FADHEL et al. 2011; }
$$
ZARTI, 2002; LAZZEZ et al., 2008; BEN FADHEL et al., 2011; OUAGHI et al., 2011)

The main aim of this study is to characterize the reservoir properties of the Aptian series in west-central Tunisia, specifi-
cally the facies evolution from the southern to northern areas, $\begin{array}{ll}\text { Sedimentary facies, Depositional environment, } & \text { study facilitated mapping of the areas exhibiting hydrocarbon reserv } \\ \text { Reservoirs structuring } & \text { from the conjunction of extensional tectonics and salt ascension. }\end{array}$ $\begin{array}{ll}\text { Sedimentary facies, Depositional environment, } & \text { study facilitated mapping of the areas exhibiting hydrocarbon reser } \\ \text { Reservoirs structuring } & \text { from the conjunction of extensional tectonics and salt ascension }\end{array}$ $\begin{array}{ll}\text { Sedimentary facies, Depositional environment, } & \text { study facilitated mapping of the areas exhibiting hydrocarbon reser } \\ \text { Reservoirs structuring } & \text { from the conjunction of extensional tectonics and salt ascension }\end{array}$

\section{INTRODUCTION}

systems including the Douleb, Semmama, and Tamesmida oil fields (Figs. 1 and 2). For many years, Aptian reservoir layers have been unexplored and untested in central Tunisia. Recently, wells area. Oil-producing wells, developed in the Douleb and Semmama area, penetrate the Aptian dolomitic reservoir. The explorelated to the structural framework of the area.

discussed the tectonic settings and geodynamic evolution of the ROLLET, 1956; DLALA, 1984; ZARGOUNI, 1985; MARsedimen, HARZALI et al., 2019). Previous stratigraphic Cretaceous palaeogeography in west-central Tunisia (Fig. 3), which is considered to represent a large transitional zone between the platform to the south, and a deep trough to the north (e.g. BISMUTH et al., 1981, MARIE et al., 1984, ZGHAL, 1994; BENTINEZ et al., 1990; BEN AYED, 1993; EL EUCHI, 1993, BOUKADI, 1994, CHIHI, 1995; RIGANE et al., 2010; ZOUAGHI et al., 


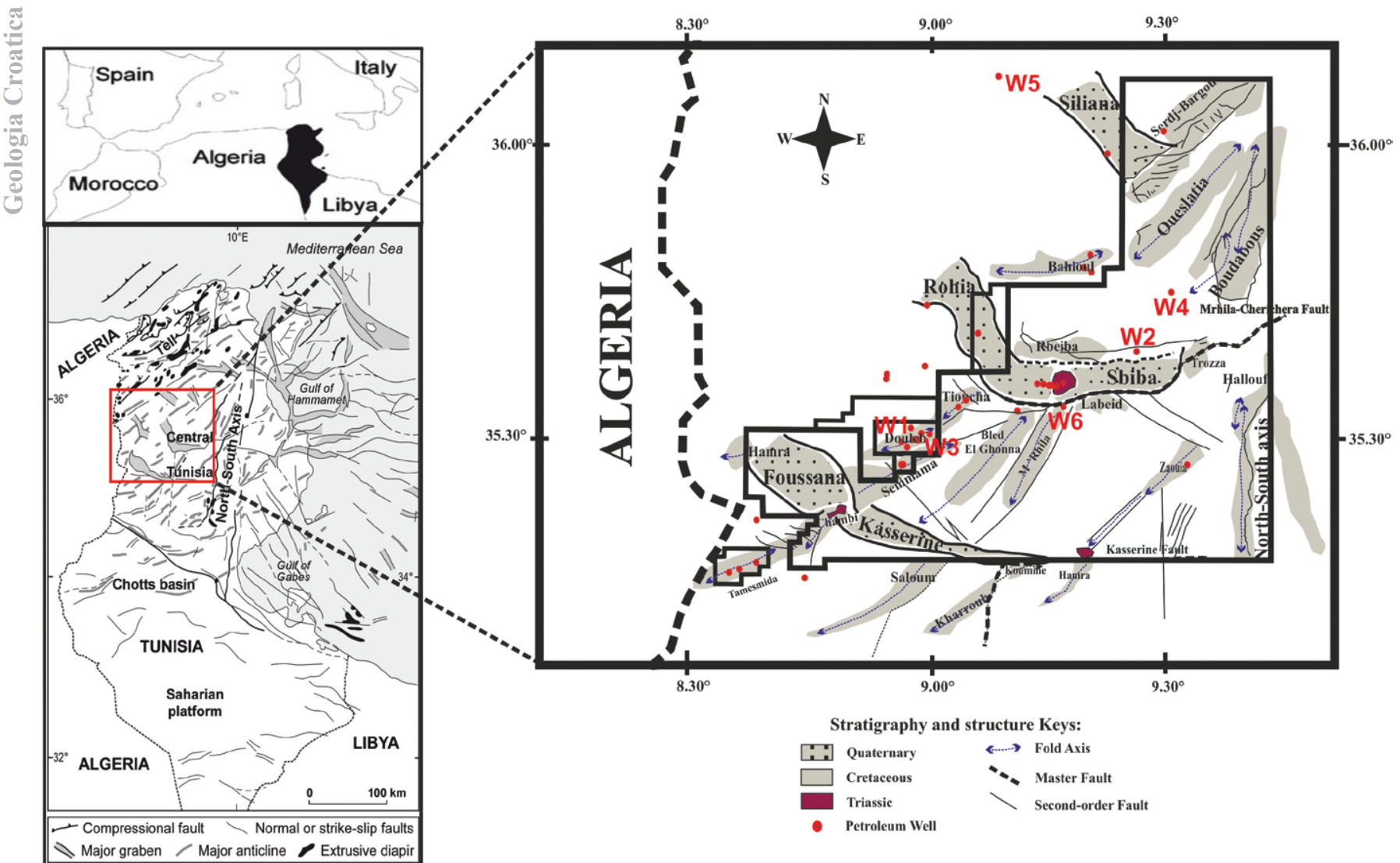

Figure 1. A structural map of Tunisia (ETAP, 2000) showing the main geological features, with the location of the study area in west-central Tunisia.

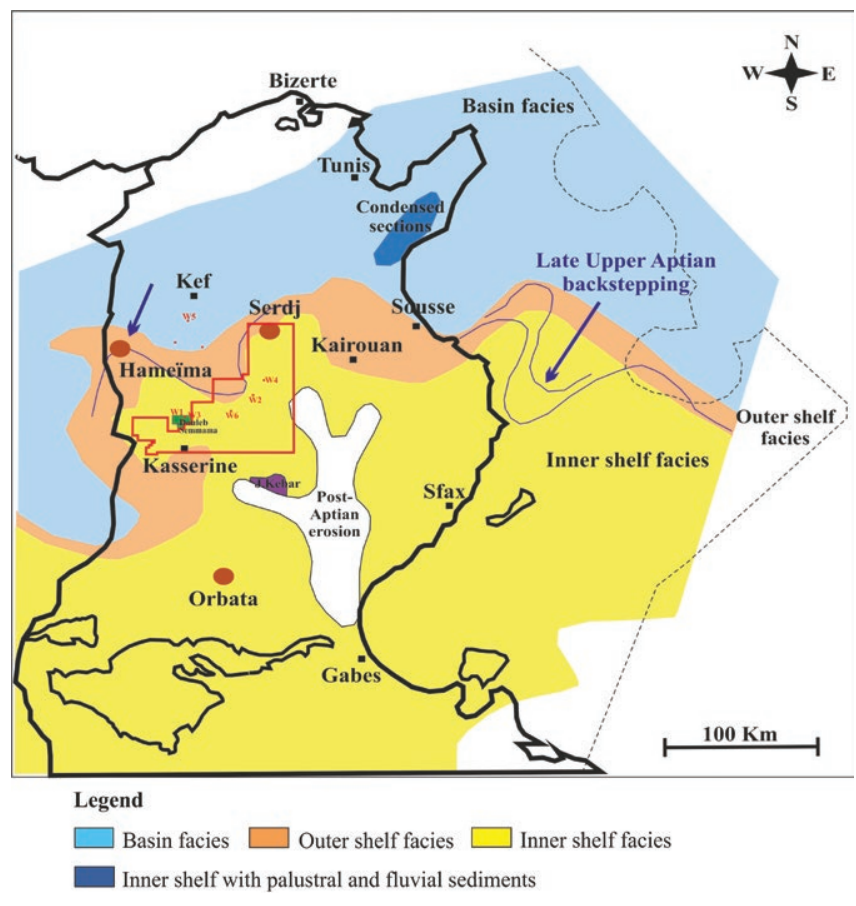

Figure 2. A palaeogeographic map of the Tunisian Aptian showing the main depositional domain from the Saharan platform in the south to the subsiding trough to the north (ZGHAL \& ARNAUD-VANNEAU, 2005).

The Aptian extensional tectonic phase has been coupled with the rising of Triassic evaporites such as salt domes, salt rollers, and salt walls (ZOUAGHI et al., 2011, 2013). This halokinetic rise is mostly highlighted at the intersection of two or more master faults, and is related to tectonic reactivation associated with stress changes (ZOUAGHI et al., 2011).

The Aptian tectonic movements in west-central Tunisia were controlled by the Tethyan tectonic evolution (e.g. DERCOURT et al., 1985; SOYER, \& TRICART, 1987; ZOUAGHI et al., 2013). These regional extensional events, fossilized in the North African plate, seem to be related to the south Atlantic opening (e.g. MARITINEZ et al., 1991; BARRIER et al., 1993; PIQUÉ et al., 1998; BÉDIR et al., 2001; BOUAZIZ et al., 2002; ZOUAGHI et al., 2005, 2011; JAILLARD et al., 2013).

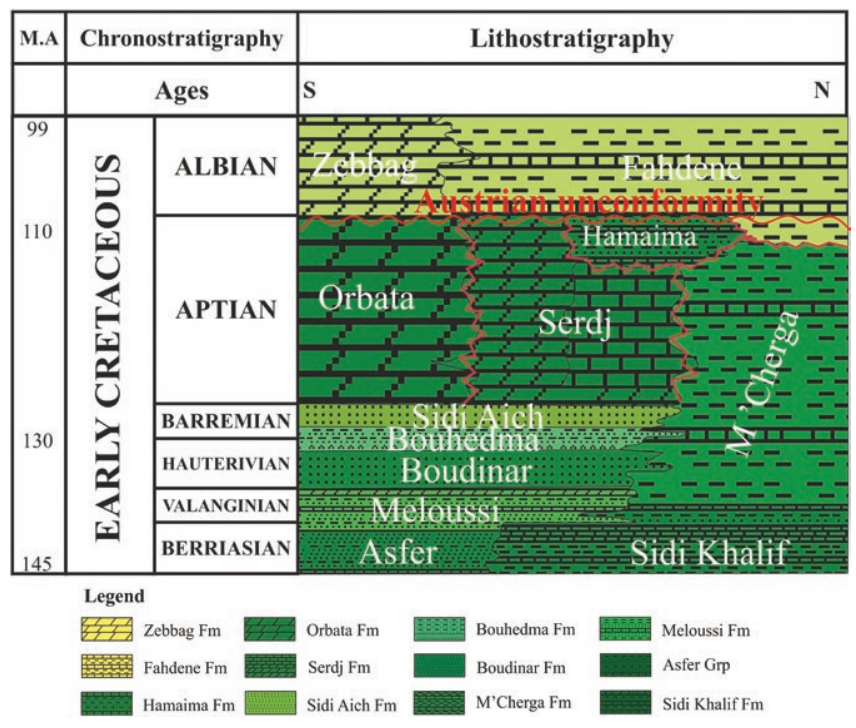

Figure 3. A lithostratigraphic chart of the Tunisian Early Cretaceous simplified from various previous studies (e.g. M'RABET et al., 1995; BEN YOUSSEF, 1999). 


\section{APTIAN PALAEOGEOGRAPHY IN WEST-CENTRAL TUNISIA}

The outcropping Aptian lithofacies covering wide areas of the Tunisian realm, reflect distinct depositional settings (Fig. 2), ranging from continental deposits in the South to marine facies northward (e.g. BISMUTH, 1973; TLATLI, 1980; BOLTENHAGEN, 1981; M'RABET, 1981; MARIE et al., 1984; ZGHAL, 1994; BENZARTI, 2002; LEHMANN et al., 2009). These successions are essentially controlled, in addition to sea-level changes, by the geodynamics of the western Tethys realm (e.g. DERCOURT et al., 1985; RICOU, 1994; BOUAZIZ et al., 2002; LAZZEZ et al., 2008; ZOUAGHI et al., 2011, 2013).

During the Aptian, the Tunisian realm was subdivided into three distinct provinces, respectively named southern, central and northern palaeogeographic domains (Fig. 2). Southern continental to lagoonal environments prevail over large areas of the Saharan Platform. Farther north, these environments transition into a shallow marine platform, extending over a larger area in both onshore and offshore domains. It is characterized by mixed inner shelf facies which consist mainly of carbonate deposits with sandstone and shale intercalations (Figs. 2 and 3). This facies indicates open marine conditions, marked by bioclastic limestones with marl intercalations and reef deposits. A high block named Kairouan Island, located in the eastern part is characterized by post Aptian erosion (Fig. 2). The northern part of Tunisia was dominated by subsiding zones with predominantly pelagic deposition marked by claystones and marlstones with intercalated turbidites (e.g. ZGHAL, 1994; ZGHAL \& ARNAUDVANNEAU, 2005).

\section{STRATIGRAPHY}

The Aptian Serdj Formation was described in the stratotype section at the Serdj anticline (BUROLLET, 1956). Several biostratigraphic frameworks dealing with the age of Serdj Formation have been established and widely discussed (e.g. BISMUTH, 1973; TLATLI, 1980; M'RABET, 1981; ZGHAL, 1994). In west-central Tunisia, the Aptian successions display lateral thickness and facies variation, and are associated with major unconformities of erosional or non-depositional events. Previous hydrocarbon exploration on the Serdj Formation have proven it to be productive as demonstrated by numerous oil and gas discoveries that have been made in the Douleb, Semmama, and Tamesmida fields.

In central Tunisia, the Serdj Formation, which overlies sands of the Barremian Sidi Aich Formation, consists mainly of carbonates including some sandstone and shale beds (Fig. 3). The limestone beds are oolitic and/or bioclastic. They display mudstone, wackstone and packstone textures and contain orbitolinids, crinoids, bryozoans, gastropods, cephalopods, pelecypods, green and red algae with locally abundant rudists and corals (e.g. BISMUTH, 1973; M'RABET et al., 1979; BUROLLET et al., 1983; ZGHAL, 1994; BENZARTI, 2002; BEN FERJANI et al., 2006; ZOUAGHI, 2008; LEHMANN et al., 2009; HELDT et al., 2010;

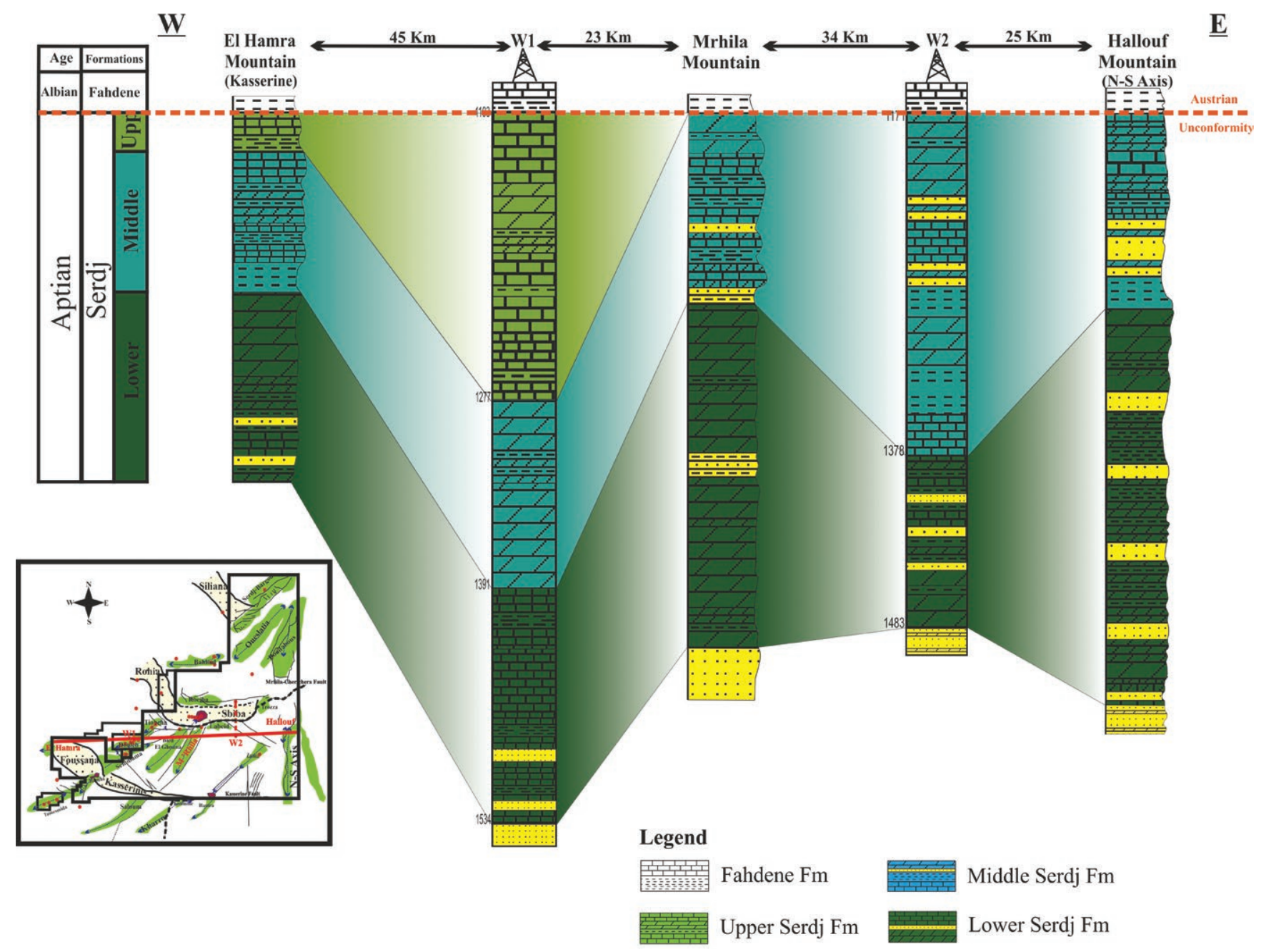

Figure 4. E-W lithostratigraphic correlation of the Aptian reservoir Formation from outcrops and wells. 


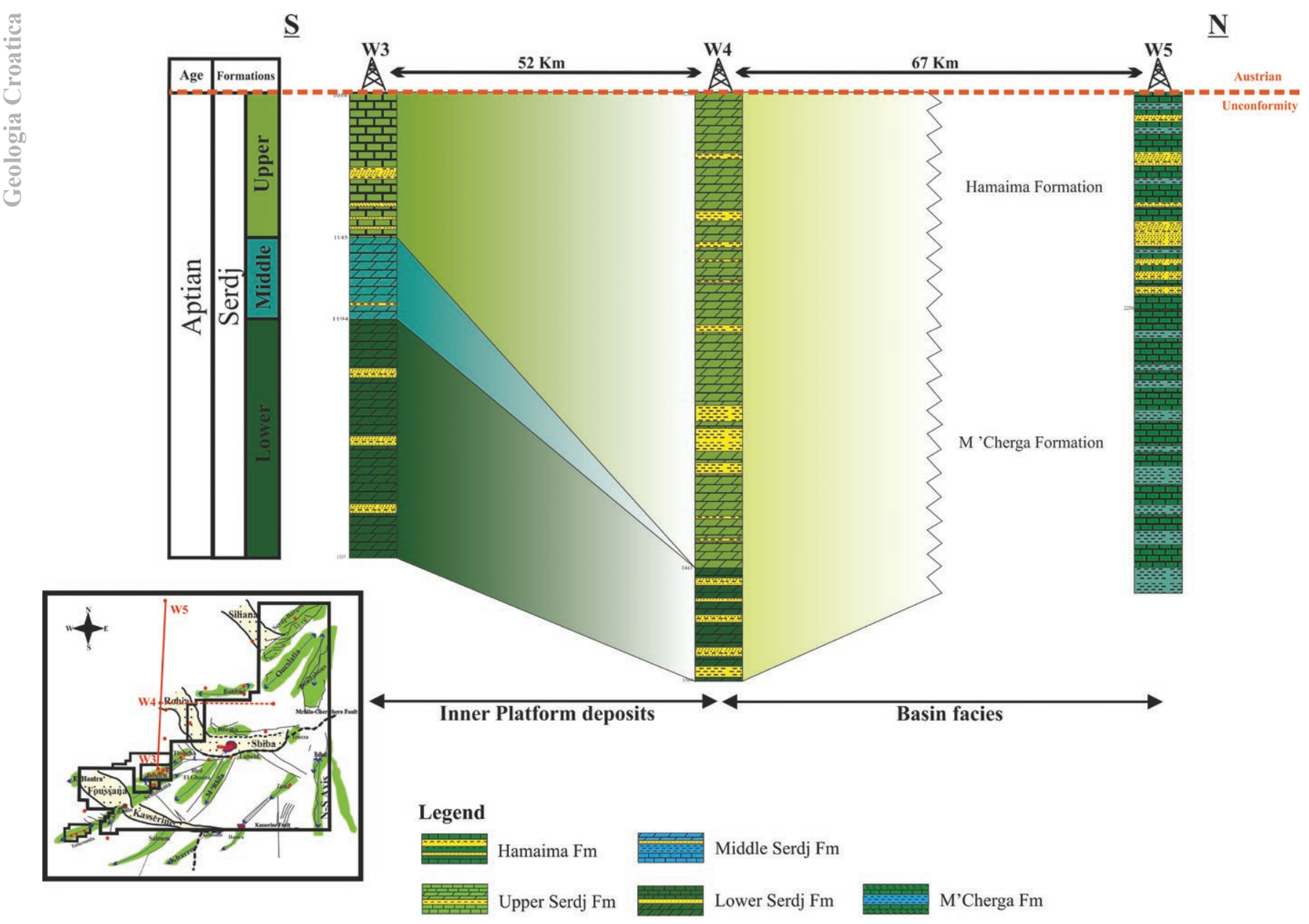

Figure 5. N-S subsurface lithostratigraphic correlation of the Aptian deposits (inner platform deposits- basin facies).

ZOUAGHI et al., 2011). Locally, to the North of the study area, rudist and coral carbonate reefs are found in the Serdj anticline of central Tunisia (TLATLI, 1980). The dolomite beds are generally massive and contain bioclastic debris including recrystallized or dissolved orbitolinids and rudists (e.g. BISMUTH et al., 1981, M'RABET et al., 1979; ZOUAGHI, 2011).

The Serdj Formation was subdivided into three different members (Figs. 4 and 5); the lower bioclastic-oolitic limestones and dolomites, partly with sand and clay layers, mark (Bedoulian-early Gargasian). The middle member (Gargasian-early Clansayesian) consists mainly of dolomite beds, associated with limestone and clastic intercalations. The upper member (Clansayesian) is represented by bioclastic limestone and dolomite.

The Serdj Formation is overlain unconformably, across almost the entire region, by deposits of the Upper Albian Fahdene Formation. The transitional horizon between the two formations is either missing, indicated by hardground surfaces, or consists of conglomeratic beds, which likely suggest sedimentary hiatuses (GHANMI et al., 2017; HARZALI et al., 2019). In the far northwestern Tunisia, green marls alternating with limestone and sandstone beds attributed to the Hamaima Formation (e.g. CHIHAOUI et al., 2010; JAILLARD et al., 2013) outline the transition.

\section{BASIN DEPOSITION}

During Aptian time, relatively varied and continuous sedimentation occurred throughout central Tunisia. The Tunisian Trough and the Gafsa Basin were subsiding domains, separated by the central Tunisian platform. This high zone is marked by the Kairouan Island, characterized by unconformities in Aptian strata on structures outcropping around the north part of the NorthSouth lineament (ZOUAGHI et al., 2011). Aptian sedimentation was controlled by extensional and/or transtensional deformation leading to multiscale fracturing in structural blocks associated with salt movements (ZOUAGHI et al., 2005; RIGANE et al., 2010).

\subsection{Sedimentary evolution}

The Aptian Serdj Formation is considered to be the main target of exploration in west-central Tunisia. This interval, containing several reservoir layers, shows lateral variation in thickness and facies. The stratigraphic correlation of the Serdj Formation, including data from deep wells and outcrops of the El Hamra, Mrhila and Hallouf structures, provided important details about the platform structure and allowed interpretation of the reservoir stratigraphic framework. Three members were characterized, demonstrating facies evolution from the inner shelf to open marine depositional environments (Fig. 4).

\subsubsection{Lower member}

The lower member, consisting of oolitic limestone beds and sandstone intercalations, is about $130 \mathrm{~m}$ thick in the El Hamra anticline and the $\mathrm{W} 1$ well. The member thickness increases progressively eastwards reaching $180 \mathrm{~m}$ in the Mrhila outcrops, $105 \mathrm{~m}$ in W2 well and $200 \mathrm{~m}$ in the Hallouf anticline outcrops. The late- 

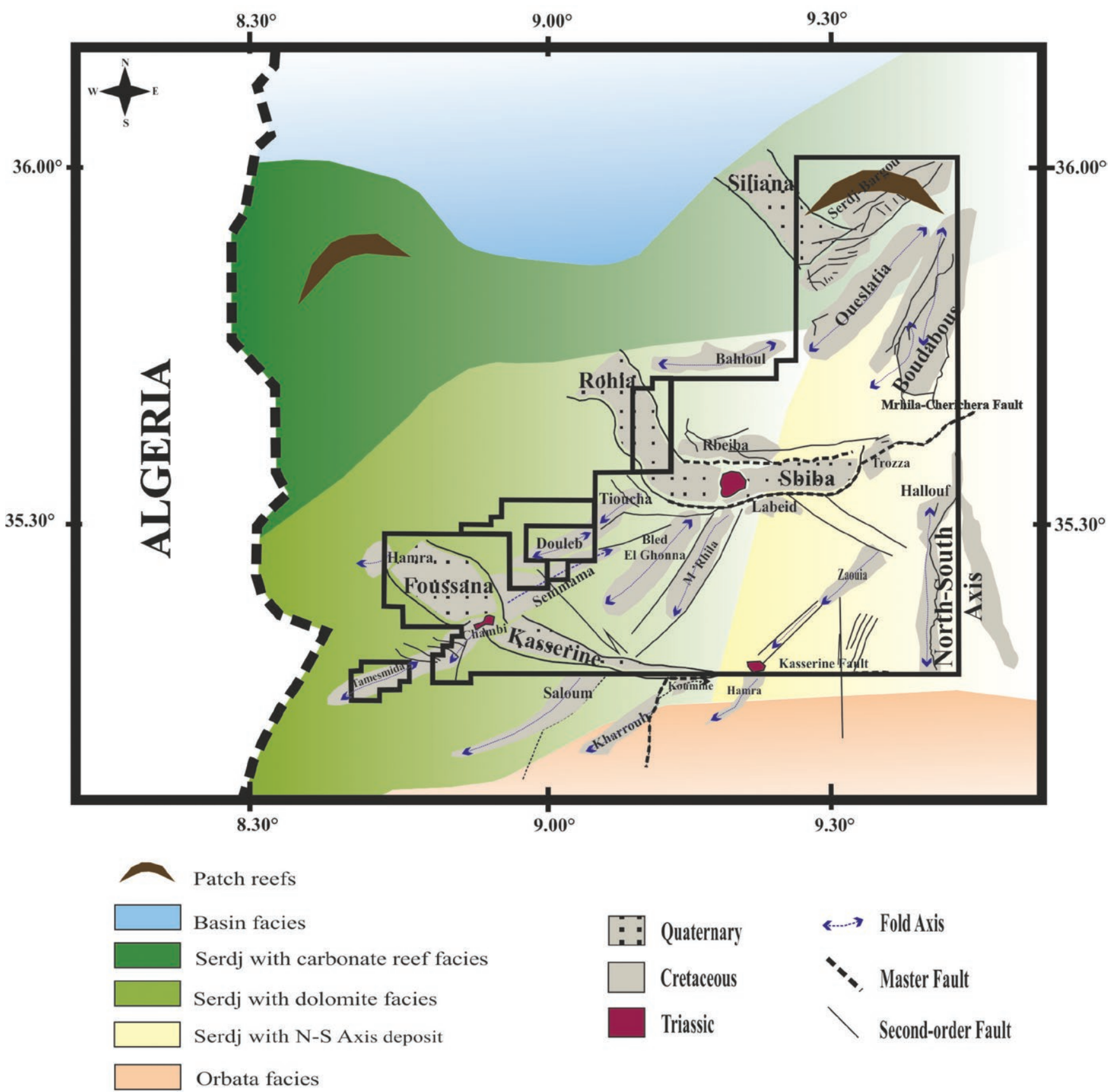

Patch reefs

Basin facies

Serdj with carbonate reef facies

Serdj with dolomite facies

Serdj with N-S Axis deposit

Orbata facies

Figure 6. Lithofacies and sedimentary environments of Aptian deposits in the study area.

ral stratigraphic equivalent of this member shows significant detrital intercalations to the East.

\subsubsection{Middle member}

The middle member is about 100 m thick in the El Hamra, Mrhila and Hallouf anticline outcrops. It consists mostly of dolomite beds, including limestone and shale intercalations in the El Hamra anticline and the W1 well, located in the western part of the study area.

To the East, the middle member shows thick detrital intercalations that can be recognized in the Mrhila, Halouf anticlines and the W2 well.

\subsubsection{Upper member}

The upper member is composed of oolitic and bioclastic carbonate layers outcropping in the El Hamra anticline and the W1 well. This member is missing in the eastern part of the study area.

\subsection{Depositional environment}

The Serdj Formation facies indicates shallow depositional marine conditions and characterized by a wide spatial extent in central Tunisia. The depositional environment grades laterally southwards to inner shelf deposition characterized by mixed carbonate, evaporite and some siliciclastic intercalations of the Orbata Formation. To the North and the Northeast, the Aptian successions correspond to an open marine carbonate shelf depositional environment that passes laterally into deep marine shale basin, the M'Cherga Formation.

The facies evolution of the Aptian reservoir indicates the presence of subsiding structures westward of the study area with thick deposition, and high zones eastward represented by Kairouan Island. To the North, the Aptian successions reflect a deep basin depositional environment (Fig. 5), represented by alternating limestone and marl layers (M'Cherga Formation) and some 


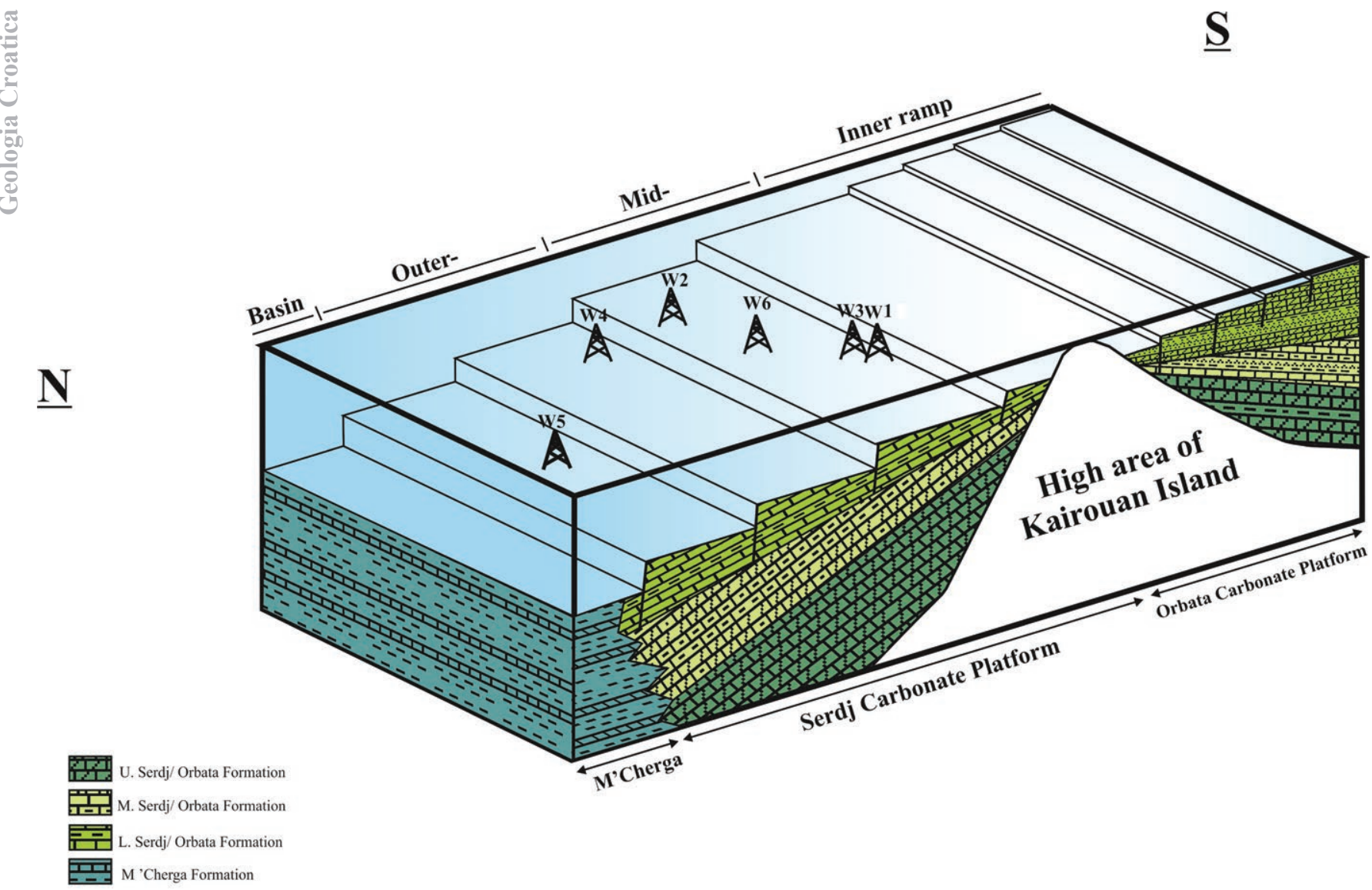

Figure 7. 3-D block diagram showing the lateral evolution of Aptian deposits from southern to northern Tunisia.

sandstone beds (the Hamaima Formation). The zone, separating the deep basin from the platform, displays horst and graben architecture linked to extensional tectonics, halokinesis and associated sea-level fall (ZOUAGHI et al., 2011). It displays a transitional depositional system characterized by carbonate sedimentation coeval with increased detrital influx (HELDT et al., 2010).

The Aptian basin configuration inherited from extensional phases and halokinesis dictated the sedimentary pattern, diagenetic processes, facies distribution and sequence geometries in West Central Tunisia, and as a consequence, controlled the mechanisms of trap development. We distinguish three areas that reveal proven reservoirs (Fig. 6): the first area, marked by dolomite reservoir facies, is considered to be the most productive domain. The second area is characterized by carbonate reef and para-reef facies. Detrital deposits characterize the third zone located in the North-South axis.

The Aptian Serdj Formation consists of bioclastic and oolitic carbonates that are affected by diagenetic processes that are active in the eogenetic zone and associated with phreatic, meteoric and vadose waters, resulting in local karstification and dolomitization (e.g. TLATLI, 1980; HELDT et al., 2010). The associated textures mostly composed of mudstone, wackstone and packstone mainly containing foraminifera, and cephalopods, indicate prevailing mid and outer ramp depositional environments in westcentral Tunisia (Fig. 7).

\section{RESERVOIR ASPECTS}

Tunisia has several proven and potential reservoirs and source rocks. In central Tunisia, the reservoirs are highly heterogeneous, mainly carbonate and secondary sandstone of Jurassic and Cretaceous age. The formation of an Aptian reservoir is associated with the uplift of reef carbonates of a barrier reef platform. The reservoir rocks are characterized by secondary porosity resulting from dissolution and karstification associated with emersion.

\subsection{Reservoir structures}

The Aptian Serdj carbonates are proven oil-producing reservoirs in central Tunisia, with an effective porosity ranging from 7 to $25 \%$ in the dolomite and around $16 \%$ in the limestone beds. Permeability ranges from 30 to 1000 millidarcy (md). The presence of fractures locally enlarged by karstification also enhances both porosity and permeability (e.g. OUAHCHI et al., 1998; ZOUAGHI, 2008; BEN BRAHIM et al., 2012). This carbonate reservoir is regionally well sealed by the Albian Fahdene shales, which contain mature source rocks (e.g. SAIDI \& BELAYOUNI,

Table 1. Petrophysical parameters (VSH, SW and Ø) in wells W4 and W6 showing levels of oil interest. (VSHGR volume of shale by GR; PHID porosity by density; SW water saturation; SH hydrocarbon saturation. The SH and SW identified by archie).

\begin{tabular}{ccccccc}
\hline Well & Total depth $(\mathrm{m})$ & Net Pay $(\mathrm{m})$ & VSHGR $(\%)$ & PHID (\%) & SW $(\%)$ \\
\hline W4 & 278 & 10.5 & 25.11 & 10.2 & 20.32 \\
W6 & 304 & 12 & 8.15 & 7.63 & 79.68 & 29.95 \\
\hline
\end{tabular}




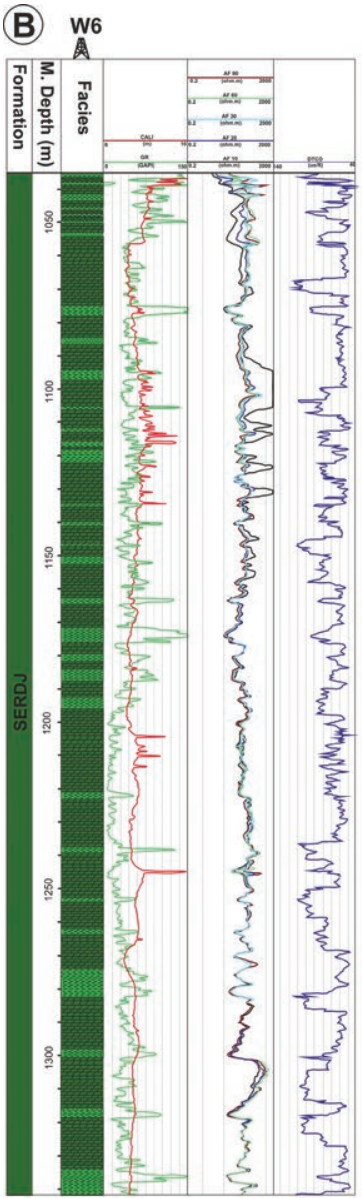

(C)
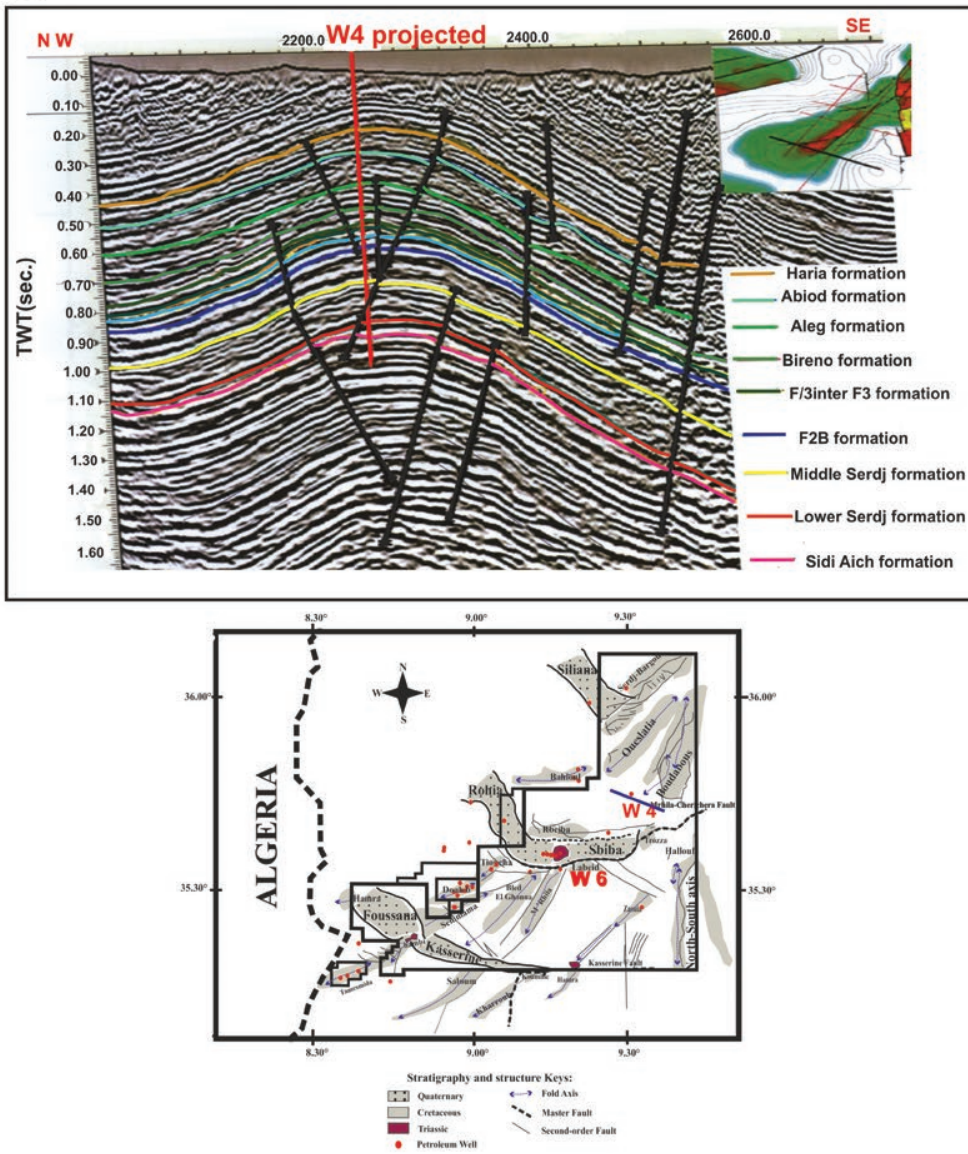

(A)

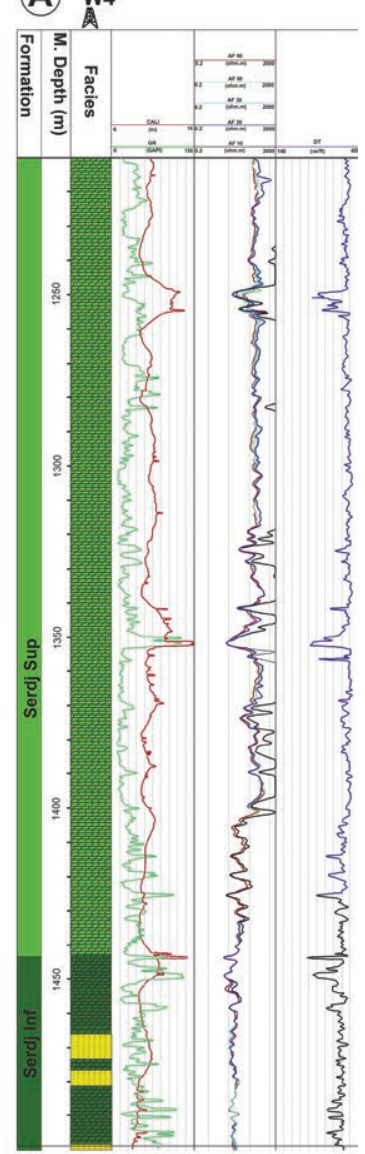

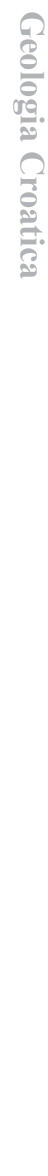

Figure 8. Seismic sections showing the anticline structure through the W4 well.

1994; BEN FERJANI et al., 2006; BEN FADHEL et al., 2011, 2014). The reservoir drainage is facilitated by the thickening and collapse of the Albian source rock. In this case, hydrocarbons have lateral trending migration related to tectonic events that caused formation of NW-trending grabens and horsts.

\subsection{Well log study}

Analysis of log data from two wells (W4 and W6, Fig. 8) has yielded petro-physical characteristics summarized in Table 1. It was postulated that the W6 well reservoir has a larger effective thickness with good porosity, while the effective thickness and porosity are reduced in the W4 well reservoir. Northward of the study area, the W5 well reservoir has yielded poor petro-physical properties, showing low matrix porosity (less than 4\%) and a high Gamma Ray shale volume (90\%). These reservoir parameters indicate a deep depositional environment that prevailed during the Aptian (ZGHAL \& ARNAUD, 2005). These results mean that the petro-physical properties increase when approaching the dolomitic zone where the petroleum system is proven. The low porosity and permeability, the limited and non-homogeneous fracture distribution, and the complex storage space, together result in uncertainties around the effectiveness of evaluating tight carbonate reservoirs.

The well tests produced only water, a failure that was probably related to late tectonic deformations. Regarding the difference between the test result and hydrocarbon saturation provided by petrophysical evaluation, the Archie equation seems to be inadequate for the tight dolomite in relation to with unavailable result agreed by low water saturation ( $\mathrm{SH}$ up to $70 \%$ in W6, table 1).

\section{CONCLUSIONS}

In west-central Tunisia, Aptian sedimentary evolution is largely controlled by structures inherited from extensional halokinesis phases associated with the opening of the Tethys ocean.

During the Aptian, west-central Tunisia was demarcated to the north by a deep basin, the carbonate platform and an uplifted area, (the so called "Kairouan Island") in the center, and the Saharian platform to the south.

In fact, the subsurface cuttings from wells, situated to the north of the study area, reveal a marine depositional environment that prevailed during the Aptian. The subsurface study is in harmony with the palaeogeographic interpretations mentioned in previous studies in this area, indicating that during the Aptian, open marine sedimentation was restricted to the northern part of the study area (NW of Tunisia) where its lateral equivalent is represented by the upper part of the M'Cherga Formation together with the base of the Fahdene Formation.

In west-central Tunisia, the Aptian Serdj Formation, which is a proven productive reservoir in the Douleb, Semmama and Tamesmida fields, consists mostly of carbonates including oolitic and/or bioclastic limestone and dolomite beds, associated with some sandstone and shale intercalations. The carbonate textures vary from mudstone, wackstone to packstone, containing foraminifera, and cephalopods indicating mid- and outer-ramp depositional environments.

We conclude that tectonic phases and salt movement closely control the distribution of the studied Aptian Serdj Formation reservoir. Extensional phases have induced the development of 
the horst-and-graben architecture. The high-energy oolitic carbonate platform was developed on the horst blocks. The latter are bounded by faults providing dolomitization and improving the porosity in carbonate beds. An ascending salt episode has been influential in the reservoir distribution and therefore, providing locally siliciclastic sediments.

The well $\log$ analysis of the Aptian reservoir using data from two wells, shows that the petrophysical qualities increase when approaching the main productive dolomite facies zone. The failure of these wells is probably related to a timing problem (young or late structuring).

This work provides a systematic approach to evaluate exploration opportunities in lateral facies distributions according to basin layout, as well as raising new important questions and/or suspicions for directing further research for deeper targets around salt domes for other areas in the northern onshore and offshore parts of Tunisia.

\section{ACKNOWLEDGEMENT}

The authors are appreciative to the ETAP, FST, and CERTE for their scientific cooperation and help.

\section{REFERENCES}

BARRIER, E., BOUAZIZ, S., ANGELIER, J., CREUZOT, G., OUALI, J. \& TRICART, P. (1993): Mesozoic paleostress evolution in the Saharian platform (southern Tunisia).- Geodinamica Acta, 6, 39-57. doi: 10.1080/09853111.1993.11105238

BÉDIR, M., BOUKADI, N., TLIG, S., BEN TIMZAL, F., ZITOUNI, L., ALOUANI, R., SLIMANE, F., BOBIER, C. \& ZARGOUNI, F. (2001): Subsurface Mesozoic Basins in the Central Atlas of Tunisia, tectonics, sequence deposit distribution and hydrocarbon potential.- American Association of Petroleum Geologists Bulletin, 85, 885-907.

BEN AYED, N. (1993): Evolution tectonique de l'Avant-pays de la chaîne alpine de Tunisie du début du Mésozoïque à l'Actuel.- Annales des Mines et de la Géologie, Tunisie, 32, $296 \mathrm{p}$.

BEN BRAHIM, G., BRAHIM, N. \& TURKI, F. (2012) : Tectonic evolution and hydrocarbon potential of the Aptian series in the Mahdia offshore area, Tunisia.- Journal of Petroleum Science and Engineering, 90, 175-190. doi: 10.1016/j.petrol.2012.04.013

BEN FADHEL, M.., LAYEB, M., HEDFI, A. \& YOUSSEF, M.B. (2011): Albian oceanic anoxic events in northern Tunisia: Biostratigraphic and geochemical insights.Cretaceous Research, 32/6, 685-699. doi: 10.1016/j.cretres.2011.04.004

BEN FERJANI, A., BUROLLET, P.F. \& MEJRI, F. (2006): Petroleum Geology of Tunisia. Mémoire ETAP n 22 , Tunis, $233 \mathrm{p}$.

BEN YOUSSEF, M. (1999): Stratigraphie génétique du Crétacé de Tunisie: micropaléontologie, stratigraphie séquentielle et géodynamique des bassins de la marge Sud et péri-téthysienne.- Thesis, Doctorat d'Etat, Université Tunis II, Tunisia, $402 \mathrm{p}$.

BENZARTI, R. (2002): Synthèse biostratigraphique du permis Jelma.- Rapport Inédit, SEREPT (Société de Recherche et d'Exploitation des Petroles en Tunisie), Tunisia, GN3833, 37 p.

BISMUTH, H. (1973): Réflexions stratigraphiques sur l'Albo-Aptien dans la région des Djebels Douleb et Semmama et son environnement (Tunisie centre-nord).- In: SOLIGNAC M. (Editor). Livre jubilaire, Annales des Mines et de Géologie, Tunisie, $n^{\circ} 26,179-212$.

BISMUTH, H., BOLTENHAGEN, C., DONZE, P., LEFÈVRE, J. \& SAINT MARC, P. (1981): Le Crétacé moyen et supérieur du Jebel Semmama (Tunisie du centreNord), évolution sédimentologique et microstratigraphique.-Cretaceous Research, 3, 171-186.

BOLTENHAGEN, C. (1981): Les séquences de sédimentation du Crétacé moyen en Tunisie centrale.- Actes du Premier Congrès des Sciences de la Terre, Tunis, 55-71.

BOUAZIZ, S., BARRIER, E., SOUSSI, M., TURKI, M.M. \& ZOUARI, H. (2002): Tectonic evolution of the northern African margin in Tunisia from paleostress data and sedimentary record.- Tectonophysics, 357, 227-253. doi: 10.1016/S00401951(02)00370-0

BOUKADI, N. (1994): Structuration de l'Atlas de Tunisie: signification géométrique et cinématique des noeuds et des zones d'interférences structurales au contact de grands couloirs tectoniques.- Thesis, Doctorat d'Etat, FST, Université de Tunis II, Tunisia, $249 \mathrm{p}$.

BUROLLET, P.F. (1956): Contribution à l'étude stratigraphique de la Tunisie centrale.Annales des Mines et de la Géologie, Tunisie, $n^{\circ} 18,342 \mathrm{p}$.
BUROLLET, P.F., MEMMI, L. \& M'RABET, A. (1983): Le Crétacé inférieur de Tunisie. Aperçu stratigraphique et sédimentologique.- Zitteliana, 10, Munchen, 255-264.

CHIHAOUI, A., JAILLARD, E., LATIL, J.L., ZGHAL, I., SUSPERREGUI, A.S., TOUIR, J. \& OUALI, J. (2010): Stratigraphy of the Hameima and lower Fahdene Formations in the Tadjerouine area (Northern Tunisia).- Journal of African Earth Sciences, 58/2, 387-399. doi: 10.1016/j.jafrearsci.2010.02.008

CHIHI, L. (1995): Les fossés néogènes à quaternaires de la Tunisie et de la mer pélagienne: leur signification dans le cadre géodynamique de la méditerranée centrale.Thesis, Doctorat d'Etat, FST, Université de Tunis II, Tunisia, 324 p.

CHIHI, L. \& BEN AYED, N. (1991): Le rôle de la fracturation précoce sur la distribution des structures récentes le long du décrochement de Kasserine.- Annales tectonicae, 5/1. 64-73.

DERCOURT, J., ZONENSHAIN, L.P., RICOU, L.E., KAZMIN, V.G., LE PICHON, X., KNIPPER, A.L., GRANDJACQUET, C., SBORSHCHIKOV, I.M., BUILLIN, J., SOROKHTIN, O., GEYSSANT, J., LEPVRIER, M., BIJU DUVAL, B., SIBUET, J.C., SAVOSTIN, J.C., WESTPHAL, M. \& LAUER, J.P. (1985): Présentation de neuf cartes paléogéographiques au 1/20.000.000 s'étendant de l'Atlantique au Pamir pour la période du Lias à l'Actuel.- Bulletin de la Société Géologique de France 8, 637-652.

DLALA, M. (1984): Étude tectonique et microtectonique de la région de Kasserine (Tunisie centrale).- Thesis, Doctorat 3ème cycle, CNRS, Université Montpellier, France, $138 \mathrm{p}$.

EL EUCHI, H. (1993): La Tunisie du Centre-Ouest de l'Aptien à l'Actuel: tectonique coulissante, dynamique sédimentaire associée et essai de caractérisation des séquences de dépôt.- Thesis, Doctorat 3ème cycle, Université Tunis II, Tunisia, $263 \mathrm{p}$.

ETAP-ENTREPRISE TUNISIENNE D'ACTIVITÉS PÉTROLIÈRES (2000): Tunisia open acreage, Tunis, Tunisia.- Imprimeries Réunies Groupe Cérès Conseil DDB, $77 \mathrm{p}$.

GHANMI, M. A., BARHOUMI, A., GHANMI, M., \& ZARGOUNI, F. (2017): AptianAlbian boundary in Central Southern Atlas of Tunisia: New tectono-sedimentary facts. Journal of African Earth Sciences, 132, 27-36. doi: 10.1016/j. jafrearsci.2017.04.030

HARZALI, M., TROUDI, H., GODET, A. \& OUALI, J. (2019): Seismic stratigraphy and hydrocarbon prospectivity of the Aptian-Albian succession along the Oued Bahloul Basin, Central Ouest Tunisia.- Journal of Iberian Geology. doi: 10.1007/ s41513-019-00100-4

HELDT, M., LEHMANN, J., BACHMANN, M., NEGRA, H. \& KUSS, J. (2010): Increased terrigenous influx but no drowning: palaeoenvironmental evolution of the Tunisian carbonate platform margin during the Late Aptian.-Sedimentology, 57/2, 695-719. doi: 10.1111/j.1365-3091.2009.01115.x

JAILLARD, E., DUMONT, T., OUALI, J., BOUILLIN, J.P., CHIHAOUI, A., LATIL, J.L., ARNAUD, H., ARNAUD-VANNEAU, A. \& ZGHAL, I. (2013): The Albian tectonic "crisis" in Central Tunisia: Nature and chronology of the deformations.- Journal of African Earth Sciences, 85, 75-86. doi: 10.1016/j. jafrearsci.2013.04.008

LAZZEZ, M., ZOUAGHI, T. \& BEN YOUSSEF, M. (2008): Austrian phase on the northern African margin inferred from sequence stratigraphy and sedimentary records in southern Tunisia (Chotts and Djeffara areas).-- Comptes Rendus Geoscience, 340, 543-552. doi: 10.1016/j.crte.2008.05.005

LEHMANN, J., HELDT, M., BACHMANN, M. \& NEGRA, M.E.H. (2009): Aptian (Lower Cretaceous) biostratigraphy and cephalopods from north central Tunisia.Cretaceous Research 30/4, 895-910. doi: 10.1016/j.cretres.2009.02.002

MARIE, J., TROUVÉ, P., DESFORGES, G. \& DUFAURE, P. (1984): Nouveaux éléments de paléogéographie du Crétacé de Tunisie.- Compagnie Française de Pétroles, Mémoire, 19, 7-37.

MARTINEZ, C., TURKI, M.M. \& TRUILLET, R. (1990): La signification des plis d'orientation méridienne dans l'Atlas tunisien centro-méridional.- Bulletin de la Société Géologique de France, 8, 843-852.

MASSE, J.P. (1984): Données nouvelles sur la stratigraphie de l'Aptien carbonaté de Tunisie centrale, conséquences paléogéographiques.- Bulletin de la Société Géologique de France, 6, 1077-1086.

M'RABET, A. (1981): Stratigraphie, sédimentation et diagenèse carbonatée des séries du Crétacé inférieur de Tunisie centrale.- Thesis, Doctorat d'Etat, Université Paris-Sud, Centre d'Orsay, France, $540 \mathrm{p}$.

M'RABET, A., DUFAURE, P. \& BUROLLET, P.F. (1979): Nouvelles données biostratigraphiques, sédimentologiques et paléogéographiques sur l'Aptien de Tunisie central.- Geobios, Mémoire spécial, 3, 213-229.

M'RABET, A., MEJRI, F., BUROLLET, P.F., MEMMI, L. \& CHANDOUL, H. (1995): Recueil des coupes types de Tunisie.- Entreprise Tunisienne d'Activités Pétrolières (ETAP), Mémoire 8B, 123 p.

OUAHCHI, A., M'RABET, A., LAZREG, J., MESSAOUDI, F. \& OUAZAA, S. (1998): Early structuring, paleo-emersion and porosity development: A key for exploration 
of the Aptian Serdj carbonate reservoir in Tunisia.- Proceedings of the 6th Tunisian Petroleum Exploration and Production Conference, Tunis, Tunisia, 267-284.

PIQUÉ, A., BRAHIM, L.A., OUALI, R.A., AMRHAR, M., CHARROUD, M., GOURMELEN, C., LAVILLE, E., REKHISS, F. \& TIRCART, P. (1998): Evolution structurale des domaines atlasique du Maghreb au Méso-Cénozoïque; le rôle des structures héritées dans la déformation du domaine atlasique de l'Afrique du Nord.- Bulletin de la Société géologique de France, 169, 797-810.

RICOU, L.E. (1994): Tethys reconstructed: plates Continental fragments and their boundaries since 260 Ma from Central America to South-Eastern Asia.- Geodinamica Acta, 7, 169-218. doi: 10.1080/09853111.1994.11105266

RIGANE, A., FEKI, M., GOURMELEN, C. \& MONTACER, M. (2010): The «Aptian Crisis » of the South-Tethyan margin: New tectonic data in Tunisia.- Journal of African Earth Sciences, 57, 360-366. doi: 10.1016/j.jafrearsci.2009.11.005

SAÏDI, M. \& BELAYOUNI, H. (1994): Etude géologique et géochimique des roches mères albo-vraconienne dans le domaine de la Tunisie centro-septentrional. In: Proceeding of the 4th Petroleum Exploration Conference.- Mémoire ETAP, 7, 91-116

SOYER, C. \& TRICART, P. (1987): La crise aptienne en Tunisie centrale, approche paléostructurale aux confins de l'Atlas et de l'Axe Nord-Sud.- Comptes Rendus de l'Académie des Sciences, Tome 305, série II, 301-305.

TLATLI, M. (1980): Etude des calcaires de l'Albo-Aptien des Jebels Serdj et Bellouta (Tunisie centrale).- Thesis, Doctorat 3ème cycle, Université d'Aixen-Provence, Marseille, France, 917 p.
ZARGOUNI, F. (1985): Tectonique de l'Atlas méridional de Tunisie. Evolution géométrique et cinématique des structures en zones de cisaillement.- Thesis, Doctorat d'Etat, Université Louis Pasteur, Strasbourg, France, 296 p.

ZGHAL, I. (1994): Etude microbiostratigraphique du Crétacé inférieur de la Tunisie du Centre Ouest.- Thesis, Doctorat 3ème cycle, Université Tunis II, Tunisia, 393 p.

ZGHAL, I. \& ARNAUD-VANNEAU, A. (2005): The Hameima Formation. AptianTuronian events in Central Tunisia. Field trip guidebook.- Géologie Alpine, sér. Spéc., 5, 101-104.

ZOUAGHI, T. (2008): Distribution des séquences de dépôt du crétacé (Aptien-Maastrichtien) en subsurface: déformation tectonique, halocinèse, évolution géodynamique (Atlas central de Tunisie).- Ph.D. Thesis, Université Tunis El Manar, Tunisia, $367 \mathrm{p}$.

ZOUAGHI, T., BÉDIR, M., AYED-KHALED, A., LAZZEZ, M., SOUA, M., AMRI, A. \& INOUBLI, M.H. (2013): Autochthonous versus allochthonous Upper Triassic evaporates in the Sbiba graben, central Tunisia.- Journal of Structural Geology, $52,163-183$.

ZOUAGHI, T., BÉDIR, M. \& INOUBLI, M.H. (2005): 2D seismic interpretation of strike-slip faulting, salt tectonics, and Cretaceous unconformities, Atlas Mountains, central Tunisia.- Journal of African Earth Sciences, 43, 464-486. doi: 10.1016/j. jafrearsci.2005.09.010

ZOUAGHI, T., BEN YOUSSEF, M., FERHI, I., INOUBLI, M.H., GASMI, M. \& BÉDIR, M. (2011): Analysis of Cretaceous (Aptian) strata in central Tunisia, using 2D seismic data and well logs.- Journal of African Earth Sciences, 61, 38-61. doi: 10.1016/j.jafrearsci.2011.05.002 